\title{
ANTIBACTERIAL EFFECT OF ROOT CANAL PREPARATION AND CALCIUM HYDROXIDE PASTE (CALEN) INTRACANAL DRESSING IN PRIMARY TEETH WITH APICAL PERIODONTITIS
}

\author{
EFEITO ANTIBACTERIANO DO PREPARO BIOMECÂNICO E DO CURATIVO DE DEMORA \\ COM PASTA À BASE DE HIDRÓXIDO DE CÁLCIO (CALEN) EM DENTES DECÍDUOS \\ COM LESÃO PERIAPICAL
}

Gisele FARIA 1 , Paulo NELSON-FILHO², Aldevina Campos de FREITAS², Sada ASSED ${ }^{3}$, Izabel Yoko ITO

\begin{abstract}
1- DDS, MSc, PhD, Graduated student (Doctor degree), Department of Pediatric, Preventive and Social Dentistry, Ribeirão Preto Dental School, University of São Paulo, Ribeirão Preto, SP, Brazil.

2- DDS, MSc, PhD, Associate Professor Department of Pediatric, Preventive and Social Dentistry, Ribeirão Preto Dental School, University of São Paulo, Ribeirão Preto, SP, Brazil.

3- DDS, MSc, PhD, Chairman Professor, Department of Pediatric, Preventive and Social Dentistry, Ribeirão Preto Dental School, University of São Paulo, Ribeirão Preto, SP, Brazil.

4- MSc, PhD, Chairman Professor, Department of Clinical, Toxicological and Bromatological Analysis, Ribeirão Preto Pharmaceutical Sciences School, University of São Paulo, Ribeirão Preto, SP, Brazil.

Corresponding address: Dr. Paulo Nelson-Filho - Departamento de Clínica Infantil - Faculdade de Odontologia de Ribeirão Preto- USP Avenida do Café, S/N- Ribeirão Preto- SP- CEP 14040-904 - Fone: (16) 3602-4099 - Fax: +55-16-633-0999 - E-mail: nelson@forp.usp.br

Received: January 31, 2005 - Modification: March 23, 2005 - Accepted: April 29, 2005
\end{abstract}

\begin{abstract}
7

The aim of this study was to evaluate the antibacterial action of root canal mechanical preparation using $2.5 \%$ sodium hypochlorite as the irrigating solution and a calcium hydroxide paste as the antibacterial intracanal dressing in human primary teeth root canals with pulp necrosis and apical periodontitis by means of microbial culture. A total of 26 root canals of human primary teeth with pulp necrosis and apical periodontitis were used. Samples were collected before, $72 \mathrm{~h}$ after biomechanical treatment and 72h after removal of the intracanal dressing. Comparison by Wilcoxon test showed that root canal mechanical preparation effectively eliminated all microorganisms in $20 \%$ of the root canals, and the intracanal dressing in $62.5 \%$; however, the cumulative action of biomechanical treatment and intracanal dressing eliminated the microorganisms of $70 \%$ of the root canals $(\mathrm{p}<0.001)$. Isolated root canal mechanical preparation presented poorer microbiological results that those obtained with root canal mechanical preparation and the use of an intracanal dressing indicating the necessity of topical application of an intracanal medication between sessions in primary teeth with pulp necrosis and apical periodontitis.

Uniterms: Tooth, deciduos; Apical periodontitis; Root canal preparation; Calcium hydroxide.
\end{abstract}

\section{RESUMO}

Q

objetivo do presente estudo foi avaliar, por meio de cultura bacteriológica, a ação antibacteriana do preparo biomecânico utilizando como solução irrigadora o hipoclorito de sódio a 2,5\% e da pasta Calen utilizada como curativo de demora em canais radiculares de dentes decíduos de humanos com necrose pulpar e lesão periapical. Foram selecionados 26 dentes decíduos de humanos portadores de necrose pulpar e lesão periapical. As colheitas microbiológicas foram efetuadas antes e 72 horas após o preparo biomecânico e 72 horas após a remoção do curativo de demora. A comparação por meio do teste de Wilcoxon mostrou que o preparo biomecânico foi eficaz na eliminação dos microrganismos dos canais radiculares em $20 \%$ dos casos e o curativo de demora em 62,5\%, enquanto que a ação cumulativa do preparo biomecânico e do curativo de demora eliminou os microrganismos em 70,0\% dos casos ( $\mathrm{p}<0.001)$. Pôde-se concluir que o preparo biomecânico, isoladamente, apresentou resultados microbiológicos inferiores àqueles obtidos quando o mesmo foi associado ao curativo de demora, mostrando a necessidade de aplicação tópica de um curativo de demora entre sessões em dentes decíduos portadores de necrose pulpar e lesão periapical. Unitermos: Dente decíduo; Periodontite periapical; Preparo de canal radicular; Hidróxido de cálcio. 


\section{INTRODUCTION}

The success of endodontic treatment depends on many factors, however the decrease or elimination of bacterial infection is one of the most important ${ }^{19}$.

In chronic endodontic infections, bacteria and their byproducts are present not only in the main root canal but also disseminated throughout the root canal system in both primary $^{2}$ and permanent teeth ${ }^{6,7}$.

One of the aims of root canal mechanical preparation associated with irrigating solutions ${ }^{4,11,15}$ in the endodontic treatment of primary teeth is to eliminate infection. However, because microorganisms are not only in the main root canal ${ }^{5}$, root canal mechanical preparation is not efficient for elimination ${ }^{15}$. Therefore, substances must be used to fight the infection in the deep and diffused regions throughout the dentine, which are inaccessible to root canal mechanical preparation and the patient's defense system ${ }^{5-7}$.

Numerous substances have been used as intracanal dressings between sessions in primary teeth with pulp necrosis, such as formocresol, camphorated paramonochlorophenol and calcium hydroxide ${ }^{3,9,11,12,15}$. However, there are few studies in the literature evaluating the efficacy of these medicaments upon the main microorganisms found in the root canals of primary teeth with pulp necrosis ${ }^{12,16,17}$.

Thus, the aim of this study was to evaluate, in vivo by microbial culture, the antibacterial action of root canal mechanical preparation associated with irrigating solution and a calcium hydroxide paste used as an intracanal dressing in root canals of human primary teeth with pulp necrosis and apical periodontitis.

\section{MATERIALS AND METHODS}

The participants of this study were 26 patients (3-7 years old) of both genders selected consecutively from patients treated at the Pediatric Clinic of the Ribeirão Preto Dental School - USP. They were in good general health and had not been treated with antibiotics for at least 3 months. This study was approved by the Faculty Ethics Committee ( $\mathrm{n}^{\circ}$. 2000.1.92.58.6).

A total of 26 primary teeth (8 root canals from maxillary incisors, 8 root canals from 8 mandibular molars and 10 root canals from 10 mandibular molars) with necrotic pulp and radiographically visible radiolucent areas in the region of the bone furcation and/or the periapical region were used. The teeth had carious lesions but the coronary structure permitted the isolation of the surgical area with a rubber dam and later restoration. They also had intact roots or at least 2/3 of preserved root, no periodontal pockets and no previous intervention of the root canals.

\section{Clinical procedures}

After antisepsis of the oral cavity by rinsing for $1 \mathrm{~min}$ with $10.0 \mathrm{~mL}$ of $0.12 \%$ digluconate chlorhexidine (Periogard, Colgate-Palmolive Ind. Brasileira, Osasco, Brazil), local anesthesia was applied and a rubber dam was placed. The surgical field was then disinfected with $1 \%$ digluconate chlorhexidine.

After removal of the carious tissue, the area was disinfected and root canal access was done with high-speed round diamond burs (KG Sorensen Indústira e Comércio, São Paulo, Brazil) and Endo-Z files (Les Fills d'August, Maillefer, Ballaigues, Switzerland), cooled with air and water.

The first bacteriological sample was collected just after crown access introducing 4 sequential sterile absorbent paper points (Tanari Industrial Ltda., Manaus, Brazil), of a number compatible with the root canal diameter. After 30s, the paper points were removed from each canal and were placed in a test tube containing $2.0 \mathrm{~mL}$ of reduced transport fluid (RTF) prepared according to Syed and Loesche ${ }^{14}$ and processed microbiologically.

For the maxillary molars samples were collected from the palatal root canal for the maxillary molars and from the distal for the mandibular molars.

In the same session, neutralization of the septic-necrotic content of the root canal was performed using $\mathrm{K}$ files (Les Fills d'August, Maillefer, Ballaigues, Switzerland) associated with $2.5 \%$ sodium hypochlorite as irrigant solution. Working length was then performed at $1 \mathrm{~mm}$ from the radiographic apex or at the limit of the root resorption level. Root canal mechanical preparation was performed with 4 K-files and instrumentation was followed by irrigation with $1.8 \mathrm{~mL}$ of 2.5 \% sodium hypochlorite, between each instrument.

The root canals were then dried with sterile absorbent paper points, a sterile cotton pellet was placed at the entrance of the root canal and the coronary opening was sealed with Cimpat (Spécialités Septodont, Saint Maur, France) and zinc oxide and eugenol cement (IRM, Dentsply Indústria e Comércio Ltda., Petrópolis, Brazil) as double coronary sealing.

After 72h, a second bacteriological sample was taken from the root canals such as the first one. The root canal was then irrigated with $1.8 \mathrm{~mL}$ of sterile saline and dried. Ethylenediaminetetraacetic acid (EDTA, Odahcan Herpo Produtos Dentários Ltda., RJ, Brazil) was subsequently applied and agitated for 3 min with a K-file. The root canal was again irrigated with $1.8 \mathrm{~mL}$ of sterile saline and dried with sterile absorbent paper points.

The root canals were then filled with Calen (S.S. White Artigos Dentários Ltda., Rio de Janeiro, Brazil) composed by calcium hydroxide $-2.5 \mathrm{~g}$, zinc oxide $-0.5 \mathrm{~g}$, colophony $0.05 \mathrm{~g}$ and polyethylene glycol $400-1.75 \mathrm{~mL}$, that was applied with a special syringe (ML, S.S. White Artigos Dentários Ltda, Rio de Janeiro, Brazil.) with a long needle (Gengibrás, 27 G Ibras CBO Ind. Bras., São Paulo, Brazil) to the working length. The complete filling of the root canal with the paste was confirmed radiographically and coronal sealing was performed as described previously.

The intracanal dressing was maintained in the root canal for 30 days and then removed by saline irrigation. The root canals were dried and followed by double coronary sealing. After the 72 h that the root canals remained empty, a third bacteriological sample was taken similar to the first one. 
The root canals were then filled with Calen paste thickened with zinc oxide and the teeth were restored.

\section{Laboratory Procedures}

At the laboratory, 4-6 glass beads and a sterile metal wing were added to the test tubes containing the samples. The tubes were agitated for 2 min in a mixer (MixtronToptronix, SP, Brazil) at maximum speed. Subsequently, serial decimal dilutions up to $10^{-5}$ were made in phosphate buffered saline (PBS) under laminar airflow. A volume of $0.05 \mathrm{~mL}$ of the pure samples and of each dilution were seeded, with a sterile calibrated pipette, onto plates containing blood agar - Ba (Difco, Detroit, USA), Mitis Salivarius agar - Ms (Difco) and blood agar supplemented with $5.0 \mu \mathrm{g} / \mathrm{mL}$ hemin and $1.0 \mu \mathrm{g} / \mathrm{mL}$ menadione - Bak (Sigma Chemical Co., St. Louis, USA). Plates containing MacConkey agar - Mc (Difco, Detroit, USA) and bacitracin sucrose agar - $\mathrm{SB}_{20}$ (Difco, Detroit, USA) were seeded up to $10^{-1}$ dilutions. $\mathrm{SB}_{20}$ was prepared according to Davey and Rogers ${ }^{2}$, modified by the substitution of sucrose with cane sugar, according to Torres $^{18}$.

To the remaining undiluted sample, $5.0 \mathrm{~mL}$ sodium thioglycolate was added (without glucose or $\mathrm{pH}$ indicator; Difco) in order to detect microorganisms present at levels less than or equal to $20 \mathrm{cfu} / \mathrm{mL}$.
Bak plates were incubated anaerobically using the GasPak system for 7-10 days; $\mathrm{Ms}$ and $\mathrm{SB}_{20}$ plates microaerobically by the candle jar system for 2-3 days and the Ba and Mc plates aerobically for $24-48 \mathrm{~h}$, at $37^{\circ} \mathrm{C}$. After incubation, colonies were counted with a stereomicroscope (Nikon, Tokyo, Japan) under reflected light and the $\mathrm{cfu} / \mathrm{mL}$ was calculated.

\section{Statistical Analysis}

The results were analyzed statistically by the Wilcoxon nonparametric test using the software GMC 8.1 (http:// www.forp.usp.br/restauradora/gmc/gmc.html).

\section{RESULTS}

Of the 26 root canals initially selected, only 20 samples remained at the end of the experiment, due to lack of patient return or to loss of the coronal seal.

As shown in Table 1, anaerobic microorganisms were present in all 20 root canals (100\%). In 6 cases (30\%), blackpigmented bacilli were found. Aerobic microorganisms were found in 12 root canals (60\%) and streptococci were present in 17 root canals (85\%). Mutans streptococci were found in 6 canals (30\%) and aerobic Gram-negative bacilli were found

TABLE 1- Microorganisms (cfu) in human primary teeth root canals with pulp necrosis and periapical lesion

\begin{tabular}{|c|c|c|c|c|c|c|c|}
\hline Case & Anaerobic & BPB & Aerobic & Streptococcus & MS & GNAB & $\begin{array}{l}\text { Thiogly } \\
\text { colate }\end{array}$ \\
\hline 1 & $13,300,000$ & 71,000 & 0 & 0 & 0 & 0 & + \\
\hline 2 & $3,600,000$ & 315,000 & 0 & 0 & 0 & 0 & + \\
\hline 3 & $9,900,000$ & 440,000 & 40 & 0 & 0 & 0 & + \\
\hline 4 & $5,350,000$ & 10,200 & 0 & 1,130 & 0 & 0 & + \\
\hline 5 & $1,260,000$ & 0 & 7,000 & 23,000 & 40 & 0 & + \\
\hline 6 & $2,400,000$ & 0 & 183,000 & 192,000 & 0 & 0 & + \\
\hline 7 & $6,400,000$ & 0 & 72,000 & 120,000 & 0 & 40 & + \\
\hline 8 & 301,000 & 0 & 1,870 & 1,370 & 0 & 0 & + \\
\hline 9 & $3,230,000$ & 101,000 & 0 & 20 & 0 & 0 & + \\
\hline 10 & 710,000 & 49,000 & 0 & 370 & 0 & 0 & + \\
\hline 11 & 140 & 0 & 0 & 40 & 0 & 0 & + \\
\hline 12 & 4,000 & 0 & 0 & 120 & 0 & 0 & + \\
\hline 13 & 4,100 & 0 & 40 & 80 & 0 & 0 & + \\
\hline 14 & 3,800 & 0 & 0 & 2,400 & 20 & 0 & + \\
\hline 15 & 140 & 0 & 80 & 120 & 0 & 0 & + \\
\hline 16 & 580,000 & 0 & 38,000 & 149,000 & 134,000 & 0 & + \\
\hline 17 & 570,000 & 0 & 3,100 & 137,000 & 1,690 & 40 & + \\
\hline 18 & 2,800 & 0 & 200 & 2,500 & 660 & 40 & + \\
\hline 19 & 8,500 & 0 & 2,600 & 2,800 & 0 & 0 & + \\
\hline 20 & 720,000 & 0 & 2,600 & 2,200 & 140 & 0 & + \\
\hline 20 & $(100 \%)$ & $6(30 \%)$ & 12 (60\%) & 17 (85\%) & $6(30 \%)$ & $3(15 \%)$ & 20 (100\%) \\
\hline
\end{tabular}

BPB = black-pigmented bacillus; MS = mutans streptococcus; GNAB = gram-negative aerobic bacillus; + = bacterial development 
in 3 root canals (15\%). Thioglycolate medium was positive in all cases.

As seen in Figure 1, the prevalence of microorganisms in the root canals after root canal mechanical preparation greatly decreased. Anaerobic microorganisms were eliminated in 7 samples (65\% reduction) $(\mathrm{p}<0.001)$ and blackpigmented bacilli were eliminated in $100 \%$ of the cases $(\mathrm{p}<0.001)$. Aerobic microorganisms were eliminated in 10 (83.3\% reduction) $(\mathrm{p}<0.001)$ of the 12 cases positive before treatment, while streptococci were not found in 11 cases (64.7\% reduction) $(\mathrm{p}<0.001)$. Mutans streptococci were eliminated in $5(83.3 \%$ reduction $)(\mathrm{p}<0.001)$ of the 6 cases positive at first sampling. Gram-negative bacilli were not quantified.

After biomechanical preparation, the microorganisms were totally eliminated in 4 cases ( $20 \%$ reduction) $(p<0.001)$, using thioglycolate medium (Figure 2).

After application of the intracanal calcium hydroxide dressing between sessions the anaerobic microorganisms were eliminated in 6 of the 7 cases positive after root canal mechanical preparation $(85.7 \%$ reduction $)(p<0.001)$. The remaining microorganisms were not quantified in any sample; thus, the dressing was efficient in eliminating quantified microorganisms (aerobic, streptococci and mutans streptococci) in $100 \%$ of the cases positive after root canal mechanical preparation ( $p>0.001)$ (Figure 1). In the thioglycolate medium, of the 16 samples positive after biomechanical preparation, microorganisms were eliminated in 10 samples (62.5\% reduction) $(\mathrm{p}<0.001)$ after application of the between session intracanal dressing (Figure 2).

The cumulative action of root canal mechanical preparation and intracanal dressing eliminated the aerobic microorganisms, the streptococci and mutans streptococci in $100 \%$ of the cases $(p<0.001)$ and also eliminated the anaerobic microorganisms in $95 \%$ of the cases $(p<0.001)$ (Figure 1). This combined action of root canal mechanical preparation and intracanal dressing completely eliminated

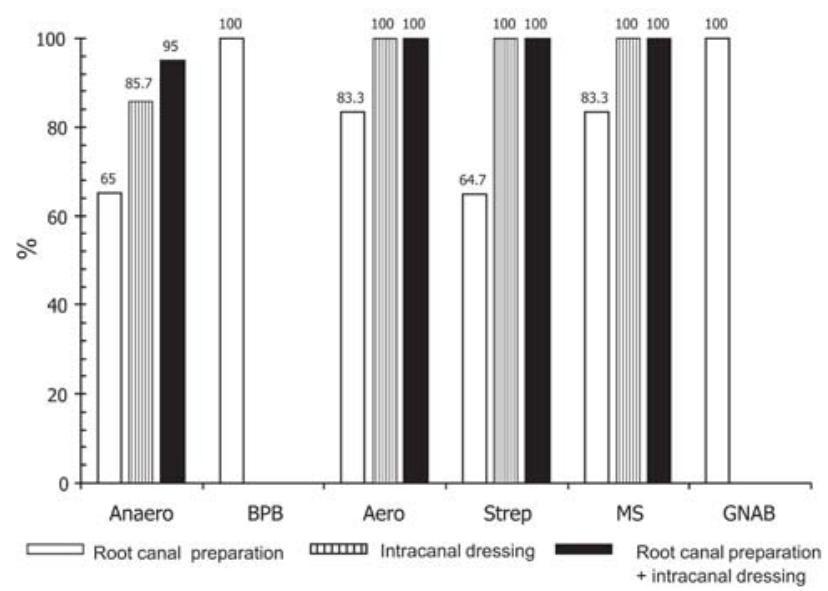

FIGURE 1- Efficiency (\%) of the biomechanical preparation, intracanal dressing and the association of both on the elimination of anaerobic microorganisms (Anaero), blackpigmented bacillus (BPB); aerobic microorganisms (Aero), streptococci (Strep), mutans streptococci (MS) and gramnegative aerobic bacillus (GNAB) the microorganisms in 14 cases $(70 \%)(\mathrm{p}<0.001)$ in the thioglycolate medium (Figure 2).

\section{DISCUSSION}

The microbiological evaluations of the root canals were performed $72 \mathrm{~h}$ after root canal mechanical preparation and removal of the dressing as recommended by Leonardo et al. ${ }^{7}$, who reported that bacteriological tests must be performed within the first 48/96 h after the endodontic intervention because the samples obtained immediately after antiseptic endodontic procedures do not reflect the real root canal system microbiological conditions.

In root canals of human primary teeth with pulp necrosis and apical periodontitis, the polymicrobial infection encountered had a predominance of anaerobic microorganisms. We observed that the root canal mechanical preparation led to a statistically significant reduction in the number of all evaluated microorganisms when compared to the initial counts (Figure 1). This was also true for the thioglycolate medium (Figure 2). However, this reduction was significantly greater with the combined action of root canal mechanical preparation and the intracanal dressing (Figures 1 and 2). These results are in accordance with Byström and Sundqvist ${ }^{1}$; Sjogren and Sundqvist ${ }^{13}$ and Rodrigues and Biffi ${ }^{10}$ who reported that in permanent teeth root canal mechanical preparation was not efficient in completely eliminating endodontic infection. Our results confirm that this is also true for primary teeth.

The maintenance of endodontic infection after root canal mechanical preparation probably occurred because in primary teeth with pulp necrosis and apical periodontitis as well as in permanent teeth, bacteria were not only present in the main canal but also frequently found in the dentinal tubules, forming biofilm in the external radicular surface at the apical region ${ }^{5,8}$ which is inaccessible biomechanical preparation $^{7}$.

A real comparison of the decrease of the microbiota due to Calen paste with literature is impossible due to the lack of

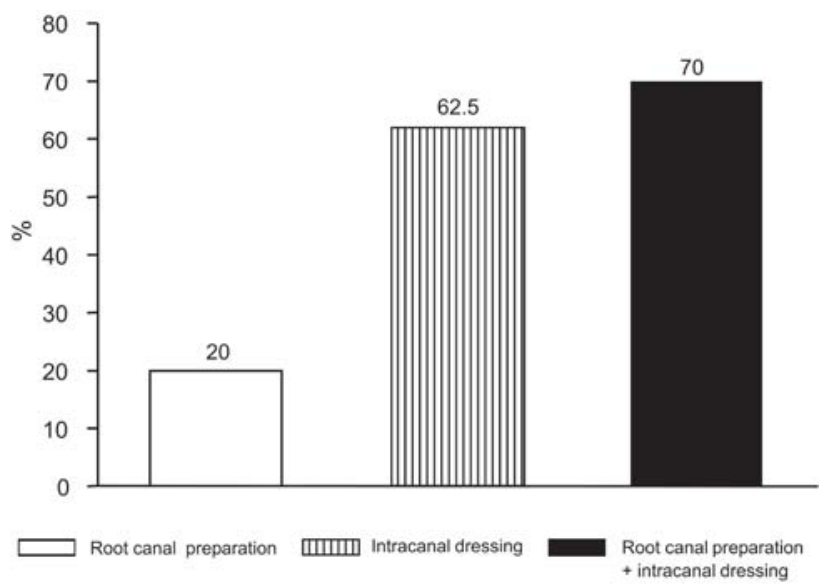

FIGURE 2- Efficiency (\%) of the biomechanical preparation, intracanal dressing and the association of both on the elimination of microorganisms in the thioglycolate medium 
in vivo studies evaluating the action of intracanal dressings in primary root canals.

The comparison between root canal mechanical preparation (20.0\%) and the cumulative action of root canal mechanical preparation and intracanal dressing (70.0\%) for the elimination of microorganisms from the root canal shows that the endodontic treatment of primary teeth with pulp necrosis and apical periodontitis cannot be performed in only one session. Therefore, our results indicate that the intracanal dressing is an important part of endodontic treatment in primary teeth with pulp necrosis and apical periodontitis.

\section{CONCLUSIONS}

Isolated root canal mechanical preparation showed inferior microbiological results (20\%) when compared to its association with intracanal dressings (70\%) indicating the necessity of topical application of an intracanal medication between sessions in primary teeth with pulp necrosis and apical periodontitis.

\section{REFERENCES}

1- Byström A, Sundqvist G. The antibacterial action of sodium hypochlorite and EDTA in 60 cases of endodontic therapy. Int Endod J. $1985 ; 18: 35-40$

2- Davey AL, Rogers AH. Multiple types of bacterium Streptococcus mutans in the human mouth and their intra-family transmission. Arch Oral Biol. 1984;29:453-60.

3- Garcia-Godoy F. Evaluation of an iodoform paste in root canaltherapy for infected primary teeth. J Dent Child. 1987;54:30-4.

4- Goerig AC, Camp JH. Root treatment in primary teeth: a review. Pediatr Dent. 1983;5:33-7

5- Hobson P. Pulp treatment of deciduos teeth. Factors affecting diagnosis and treatment. Br Dent J. 1970;128:232-8.

6- Leonardo MR, Almeida WA, Ito IY, Silva LAB. Radiographic and microbiologic evaluation of postreatment apical and periapical repair of root canals of dog's teeth with experimentally induced chronic lesion. Oral Surg Oral Med Oral Pathol. 1994;78:232-8.

7- Leonardo MR, Leal JM, Lia RCC, Martins JCR. Filosofia do tratamento de canais radiculares. Necropulpectomia: conceituação. In: Leonardo MR, Leal JM. Endodontia: tratamento de canais radiculares. $3^{\text {th }}$ ed. São Paulo: Panamericana; 1998. p.127-57.

8- Leonardo MR, Rossi MA, Silva LAB, Ito IY. EM evaluation of bacterial biofilm and microorganisms on the apical external root surface of human teeth. J Endod. 2002;28:815-8.

9- Rifkin A. A simple, effective, safe technique for the root canal treatment of abscessed primary teeth. J Dent Child. 1980;47:43541.

10- Rodrigues HH, Biffi JC. A histobacteriological assessment of non-vital teeth after ultrasonic root canal instrumentation. Endod Dent Traumatol. 1989;5:182-7.
11- Rosendahl R, Weinert-Grodd A. Root canal treatment of primary molars with infected pulps using calcium hidroxide as a root canal filling. J Clin Pediat Dent. 1995;19:255-8.

12- Sato T, Hoshino $\mathrm{E}$, Uematsu $\mathrm{H}$, Noda T. In vitro antimicrobial susceptibility to combinations of drugs of bacteria from carious and endodontic lesion of human primary teeth. Oral Microbiol Immunol. 1993;8:172-6.

13- Sjögren U, Sundqvist G. Bacteriologic evaluation of ultrasonic root canal instrumentation. Oral Surg Oral Med Oral Pathol. 1987;63:366-70.

14- Syed AS, Loesche WJ. Survival of human dental plaque flora in various transport media. Appl Microbiol. 1972;24:638-44.

15- Tagger E, Sarnat H. Root canal therapy of infected primary teeth. Acta Odontol Pediat. 1984;5:63-6.

16- Tchaou WS, Turng B-F, Minah GE, Coll JA. Inhibition of pure cultures of oral bacteria by root canal filling materials. Pediatr Dent. 1996;18:444-9.

17- Tchaou WS, Turng B-F, Minah GE, Coll JA. In vitro inhibition of bacteria from root canals of primary teeth by various dental materials. Pediatr Dent. 1995;17:351-5.

18- Torres AS. Avaliação do ágar $\mathrm{SB}_{20}$ e $\mathrm{MSB}$ na contagem de streptococos do grupo mutans na saliva e na placa dental de adolescentes. Araraquara; 1991. [Tese de Doutorado - Faculdade de Odontologia de Araraquara da UNESP].

19- Tronstad L. Recent development in endodontic research. Scand J Dent Res. 1992;100:52-9. 